guiding learned and lay people by universalising the consultancy as one in old age psychiatry. Clearly with the sub-specialism now being recognised as such there is a need for uniformity.

Gulson Hospital

J. A. ВоODHOO

Coventry CVI $2 H R$

DeAR SirS

I agree. The specialty (not subspecialty) is Old Age Psychiatry. Colleagues are encouraged to use this designation and to ask their employing authorities to do the same. They are also asked to collect data to reflect their work under the heading OAP!

Chairman

DAVID JOLLEY

Section for the Psychiatry

of Old Age

\section{Psychiatric court reports}

Dear SirS

In Hong Kong, I share the opinion of Dr Azuonye (Psychiatric Bulletin, 1991, 15, 576). Similar difficulties are encountered by local forensic psychiatrists in the preparation of court reports.

For more serious cases heard in the District Court or the High Court, there is usually a 'Summary of Facts' prepared by the Prosecution which describes the circumstances of the offence. Witnesses' statements can be traced if necessary. However, most of the cases are heard in the Magistrates Court and this is where the problem lies. The criminal history and sometimes the brief facts of the case, which are prepared by the police, are often not available before the scheduled court hearing date. In such cases, the police are reminded by phone calls and letters. I have occasionally written to the Magistrate direct stating the reason of delayed provision of psychiatric reports.

I agree with Dr Campbell (Psychiatric Bulletin, $1991,15,576-577)$ that persistence is required in obtaining useful information from other parties. However, our persistence should not be limited to individual cases; it should be consistent in our daily practice to avoid preparation of misinformed reports. The legal profession and the police should be made aware that undue adjournment of the hearing because of insufficient information supplied to the psychiatrists is both unfair and anxiety provoking to the defendants.

Castle Peak Hospital

Michael. G. C. Yiu

\section{The psychiatric liaison schemes to magistrates' courts}

DeAR SirS

In Home Office Circular $66 / 90$ on provision for mentally disordered offenders, several schemes for psychiatric liaison to magistrates' courts were described as examples of good practice. We have been running a similar scheme at Clerkenwell Magistrates' for the last 18 months and have published some of our findings (James \& Hamilton, 1991). We hear rumour of many similar schemes being planned or initiated in other parts of the country.

The joint Home Office/Department of Health Review into this area is gathering information from many quarters and is due to report in mid-1992. But as yet, there is no central co-ordination or register of court liaison initiatives, and no forum in which to share or compare experience. We wish to collect details of all court liaison initiatives in order to rectify this situation, and would be very grateful if all those who participate in, or have knowledge of such schemes, would write to us with details.

DA VID V. JAMES LYLE W. HAMILTON

The Royal Free Hampstead NHS Trust Hampstead, London NW3 $2 Q G$

\section{Reference}

James, D. V. \& Hamilton, L. W. (1991) The Clerkenwell Scheme: assessing efficacy and cost of the psychiatric liaison service to a magistrates' court. British Medical Journal, 303, 282-285.

\section{Lack of information on prison visits}

\section{DeAR SiRs}

I have been struck for many years by the lack of background information in the prison medical records when visiting prisoners on remand to prepare psychiatric reports. The situation came to a head when on one visit, the only information in the prison medical notes was? GBH? Murder!

A barrister friend advised me to write to the Lord Chief Justice, Lord Lane, which I did in November 1989. With apologies for the delay, I have just received a most helpful response, which I think is of general interest.

I received a copy of a letter from Sir Allan Green, former Director of Public Prosecutions, to Lord Lane, which reads as follows.

"You may recall that you wrote to me on 21 November 1989 enclosing correspondence from Dr Richard Lucas about the lack of information available to doctors who are asked to prepare psychiatric reports on prisoners remanded in custody. 